\title{
The Untold History of Neocolonialism in Africa (1960-2011)
}

\author{
Md. Shafiqur Rahaman ${ }^{1}$, Md. Rawshan Yeazdani ${ }^{2}$, Rashed Mahmud ${ }^{2}$ \\ ${ }^{1}$ Department of History and Bangladesh Studies, Pabna University of Science \& Technology, Pabna, Bangladesh \\ ${ }^{2}$ Department of English, Pabna University of Science \& Technology, Pabna, Bangladesh
}

\section{Email address:}

Shafiq87history@gmail.com (Md. S. Rahaman), yeazdani.pust@gmail.com (Md. R. Yeazdani), rashed.sust07@gmail.com (R. Mahmud)

\section{To cite this article:}

Md. Shafiqur Rahaman, Md. Rawshan Yeazdani, Rashed Mahmud. The Untold History of Neocolonialism in Africa (1960-2011). History Research. Vol. 5, No. 1, 2017, pp. 9-16. doi: 10.11648/j.history.20170501.12

Received: January 13, 2017; Accepted: February 21, 2017; Published: March 14, 2017

\begin{abstract}
After the Second World War, the imperialist trends of the eighteenth and nineteenth century began to decline. Through collective struggles, the Africans achieved independence from the whites. But though they attained freedom, they could not imagine the fact that it was just a treacherous exchange of power between the out-going masters and few of their faithful heirs. In the colonial period, the European rulers propagated that as the Africans had no culture and history of their own, it was their holy duty to civilize the native Africans. Thus, they regarded themselves superior to Africans whose culture they considered inferior, uncivilized, and savage. In the name of spreading civilization, they dominated, oppressed, tyrannized and persecuted the native Africans not only economically and politically, but also culturally. When the Europeans left, the Africans got political freedom, but the foul practice of imperialism did not end. It appeared in a new form namely neocolonialism which the scholars had branded as the worst form of imperialism. This camouflaged imperialist practice is turning Africa into a museum of acute poverty, hunger, corruption and famine. The paper aims at elucidating the effects of neocolonialism in Africa from four major perspectives- economic, political, cultural and literary.
\end{abstract}

Keywords: Africa, Neocolonialism, Imperialism, Cultural Imperialism, Disillusionment of African Writers

\section{Introduction}

In the immediate aftermath of the Second World War and in the changing scenario of the world politics the previous imperialist power (Britain, France, Germany, Belgium, etc.) had collapsed and the neo-imperialist countries like the USSR and the USA appeared on the stage. The influence of these neo-imperialist countries led to the decolonization of Africa which began in the 1960s. But the colonial traditions and the dirty games of the former and present imperialist power kept Africa within the iron curtain of neocolonialism. The African states achieved independence in politics, but they remained dependent on their colonial masters both economically and socio-culturally. As a consequence, Africa could not come out from the curse of poverty, hunger, corruption and famine; and underdevelopment was a common term in their arena. Their sufferings remind the world of the stories of dead children in the famines of SubSaharan Africa- Ethiopia, Eritrea or Somalia. But why is Africa in this condition? To find answer to this question, in our research we will unveil such untold histories of Africa which the researchers usually did not say.

\section{Definition of the Neocolonialism}

The term 'neocolonialism' was first coined by Kwame Nkrumah. For Kwame Nkrumah, "neocolonialism represents the final stage of imperialism. Neocolonialism is the worst form of Imperialism: for those who practice it, it means power without responsibility, and for those who suffer it, it is exploitation without redress" [1] Predominantly Neocolonialism has no definite definition. It has western, Asian and African versions of the definitions. Encyclopedia Britannica, the Worldwide accepted knowledge book where Sandra Halperin defined neocolonialism, "Neocolonialism, the control of less-developed countries by developed countries through indirect means." [2] Sandra Halperin has explained the 'indirect means' as the developed countries are dominating underdeveloped or developing countries indirectly by using colonial exploitation rules. For example, in the contemporary world, The Latin American and African underdeveloped or developing countries are affecting 
perniciously by the imperialist countries. She added "the term neocolonialism was originally applied to European policies that were seen as schemes to maintain control of African and other dependencies." [3] Basically, Neocolonialism is a process by which colonial mother country exposed exploiting rules and regulations to her newly independent underdeveloped countries or less developing countries for indirect dominating; the dominating can be economic and political or cultural. Predominantly neocolonialism has noticed in economics, although this economic exploitation is cloaked by the political and cultural exploitation. Scholarly said, after the Second World War, the colonies were acquiring independences politically but the imperialist countries didn't give those states economic independences. In such a degree, the newly acquired independent countries must have to depend on her colonial country. As the Bengali poet Jibonanonda Das writes:

All are our crops; but we get from others

To middleman those are not from others.

Yet they show them our jam-packed granary.

Faces of our decrepit doctors,

Inspiration of our lawyers,

All go into their possession. [4]

\section{The Untold History of Africa}

The colonial story of Africa is not disparate from other colonial countries like India, China, Myanmar, Indonesia and Malaysia. Rather, their history of disparity and oppression is very coequal. The African colonial history had begun from the Berlin conference on 13 November 1884- 26 February 1885. [5] The foremost agenda of the conference was how to allocate African regions among the European powers. [6] At the end of the meeting, the European powers were lunged to apportion Africa. [7] Following the way, the European powers were occupied the whole of African regions except Ethiopia and Liberia within 1900. After the Second World War, the colonial oppression rules became flimsy and the nationalist leaders were demanding for the full independence of Africa. During the postwar world, the United States and the Soviet Union had appeared as a world super power and the world system had become changed. [8] The two super powers had taken anti-colonial steps to collect new ally in the polarized world. The United Nations also limpidly declared on UN charter article 73:

Members of the United Nations which have or assume responsibilities for the administration of territories whose Peoples have not yet attainted a full measure of selfgovernment recognize the principle that the interest of the Inhabitants of these territories are paramount, and accept as a trust the obligation to promote to the utmost, within the system of international peace and security established by the present charter, the well-being of the inhabitants of these territories, and, to this end... [9].

Following the way, the decolonization of Africa had begun in 1960's. In this decade more than 15 African colonies achieved independence. [10] But the colonial powers did not give those states economic independence. Hence, Kwame Nkrumah said, the African independence was a one kind of farce. He critiqued this capitalist system as 'neocolonialism'. We will elucidate the neocolonialism effect in Africa from four major perspectives such as, economic, political, cultural and literature.

\subsection{Economic}

Economy is the driving force for the development of any country. Without economic development, no countries can achieve development. In the African context imperialist countries had applied economic tools as an arm to dominate the newly independent countries. After the decolonization, the African states have had must victim of the imperialist powers. During the decolonization Kwame Nkrumah, the president of the Ghana, who stated, Neocolonialism is the worst form of imperialism and the highest stage of capitalism (Nkrumah, Neocolonialism ix). For Nkrumah, it is such a system by which colonial power like Britain, Germany, France and Belgium gave the liberation to the colony in one hand but in the other hand they robbed this liberation. He thought, without economic independence, the political independence is vain and the absolute liberty will not come. On 30 December 1965, a neocolonial critique was published on the daily Azad, the prominent newspaper of the then East Pakistan, where the editor had explained the ultimate goal of the neocolonialism was to transform into newly independent country to under develop country and at any cost, the imperialist countries wanted to do so. As a consequence the sovereign country lost his sovereignty and colonial exploitation became a continuous process to this country and the intriguing was substantializing by the capitalist country like the USA. But the meaning of neocolonialism was not that had to stop invest in under developed countries but the real meaning would invest in less developed countries that countries would get most of the profit of the invest. [11] On the other hand, the war of neocolonialism is greater than the political war. Kwame Nkrumah said, "we again rededicate ourselves in the struggle to emancipate other countries in Africa; for our independence is meaningless unless it is linked up with the total liberation of the African continent". [12] This 'meaningless independence' referred the economic exploitation of Africa and the process was begun from the colonial rule. Moreover, African states have estimated $53 \%$ of the world industrial minerals and metals reserves. Nkrumah claimed "but her resources have been and still are being used for the greater development of the overseas interest." [13].

Table 1. African Economic Exploitation in 1957.

\begin{tabular}{|c|c|c|c|c|c|}
\hline To Britain & 1957 & To France & 1957 & To Germany & 1957 \\
\hline $\begin{array}{l}\text { Tin ore and } \\
\text { Concentrates }\end{array}$ & $19 \%$ & Cotton & $32 \%$ & Copper & $8 \%$ \\
\hline Iron & $29 \%$ & Iron ore & $36 \%$ & Iron ore & $10 \%$ \\
\hline Manganese & $80 \%$ & Zinc Ore & $51 \%$ & Manganese & $20 \%$ \\
\hline Copper & $46 \%$ & Lead & $85 \%$ & Lead ore & $12 \%$ \\
\hline Bauxite & $47 \%$ & Phosphates & $100 \%$ & Chrome ore & $22 \%$ \\
\hline Chrome ore & $50 \%$ & & & Phospehorites & $71 \%$ \\
\hline Asbestos & $66 \%$ & & & & \\
\hline Cobalt & $82 \%$ & & & & \\
\hline Antimony & $91 \%$ & & & & \\
\hline
\end{tabular}

Source: Neo-colonialism the Last Stage of Imperialism, p. 2 
Such exploitations were not the only way of colonial economic exploitation but colonial power exploited Africa by several ways those were beggar description. As follows, Africa was totally unable to grow capitals, technologies, experts and stand of managements to run new independent states. The agents of the former imperialist countries, the World Bank, IMF and IFIC had taken this opportunity appropriately to bound Africa in the neocolonial iron curtain. The WB and the IMF are lending loans to African states with hard terms and conditions. Debt recipient countries have to pay back with interest that was more than that they had accepted from the agents. Because of lacking capitals, technologies and experts the agents compels to depend fully on them. The reality is African states have no options to be free from the imperialist curtain. The World Bank is lending loan to more than 140 countries in the world, among the countries, 41 African states are most debt recipient's countries in the world. Those states have lowest per-capita incomes and life of expectancy without South Africa and Botswana. The Harvard scholar Garikai Chengu elucidated African neocolonialism in global research; he said Africans' second liberation war is continuing against neocolonialism. He explained on his research paper:

The World Bank estimates that a staggering 65 percent of sub-Saharan Africa's best arable land is still controlled by white settlers or multinational corporations. The World Bank also estimates that as much as 70 percent of the net wealth in sub-Saharan Africa is owned by non-indigenous Africans or foreigners. Nowhere is this racial disparity more acute than in Africa's richest nation. South Africa is the continent most powerful nation; however, it is the continent's most economically colonized nation. The American investment bank, Citi group, recently ranked South Africa as the world's richest country, in terms mineral reserves, worth an estimated $\$ 2.5$ trillion. South African whites and western foreigners own a staggering 80 percent of this wealth. [14]

This is the real account of neocolonialism in Africa.

\subsection{Economic Drain and Debt}

From the colonial period, economic drain became an endless process in Africa. Nationalist and anti-colonialist historian and scholars have claimed that colonial economic drain is responsible for the underdevelopment of the Africa. In the 1960s the British businessmen had invested 1600 million pounds in Africa and they earned 15\% profits but they drained all profits to England. In 1949 they earned 6.7 million pounds from gold trade and in the following year they drained 3 million pounds to England. In 1958 German central bank had invested an adequate amount of Deutschmark to 100 African companies but the central bank's conditions were, they would transfer all profits to Germany. After the decolonization, the African leaders had tried to stop drain but the donor's group gave clear-cut threat to the African states authority. They declared if the anti-drain economic acts were active, we would be totally unable to invest any amount of dollar in Africa. [15] Moreover, the best ways to drain economy from developing or under developing countries are draining of raw-materials to imperialist country. A research on African economy, published on 25 may 2015in Global Research where had explained:

A rough diamond mined in Africa costs about $\$ 40$ per carat, and a diamond cut and polish in Europe increases to $\$ 400$ per carat. That same stone fetches around $\$ 900$ per carat when it reaches the consumer. Another example is Zimbabwe, which is known for producing the best quality tobacco in the world and last year it earned $\$ 650$ million from the sale of raw tobacco. Industry experts illustrate how Zimbabwe could have earned $\$ 6.5$ billion instead of $\$ 650$ million if they had processed the crop into cigarettes, rather than exporting tobacco as a raw good. Finally, Nigeria is said to sell its crude oil for a measly $\$ 9$ a barrel, only to then import refined gasoline, diesel and kerosene made from its own oil resources from hundreds of dollars per barrel. [16]

In the contemporary world, Asian giant, China has invested huge amount of dollar in Africa with tough terms and conditions and draining un-statistical dollar from Africa.

Debt is another neocolonial pivotal component which is strongly affecting African economy. The African economic scholars are saying that still now huge amount of colonial debts are not repaid by most of the African countries. Though the World Bank and IMF have decreased the debt interests but the terms and conditions are very stiffs. For this reason, the African economy does not run and cannot cope up in the competitive world. The former president of the African Development Bank, Babacar Nadiya stated that the debt relief of the WB, IMF, IDA, ADF and ADB is inadequate to diminish African external debts. A United Nations research on African debt noticed, Africa's external debt raised ominously between 1970 and 1990. In 1970, it was \$11 billion and in the early of 1980 s it reached $\$ 120$ billion. During the late 1990 s it extended to $\$ 340$ billion. [8] The UNCTAD report of 2016 has referred; African external average debts have raised $\$ 443$ billion $(22.0 \%$ of $\mathrm{GNI})$ between 2011-2013 periods.

Table 2. Risk of Debt Distress in November 2015.

\begin{tabular}{llll}
\hline Low risk (10) & Moderate risk (20) & High risk (7) & $\begin{array}{l}\text { In debt } \\
\text { distress (2) }\end{array}$ \\
\hline Benin & Angola & $\begin{array}{l}\text { Burundi } \\
\text { Central African }\end{array}$ & Sudan \\
Ethiopia & Burkina Faso & $\begin{array}{l}\text { Republic } \\
\text { Chand }\end{array}$ & \\
Liberia & Cabo Verde & Djibouti \\
Kenya & Cameroon & Ghana \\
Madagascar & Comoros & Mauritania & \\
Nigeria & Congo & Sao Tome and & \\
Rwanda & Cote d'Ivoire & Principe & \\
Senegal & Democratic republic & & \\
United & of Congo & & \\
Republic of & Gambia & & \\
Tanzania & Guinea & & \\
Uganda & Guinea-Bissau & & \\
& Lesotho & & \\
& Malawi & & \\
\hline
\end{tabular}




\begin{tabular}{llll}
\hline Low risk (10) & Moderate risk (20) & High risk (7) & $\begin{array}{l}\text { In debt } \\
\text { distress (2) }\end{array}$ \\
\hline & Mali & \\
& Mozambique & \\
& Niger & \\
& Sierra Leon & \\
& South Sudan & \\
& Togo & \\
Zambia & \\
\hline
\end{tabular}

Source: UNCTAD, Economic Development Africa Report 2016, p. 26, IMF, 2015a updated November 2015 with available IMF country reports and debt sustainability analysis

\section{Politics}

Though African states achieved independence in the 1960s, the former colonial powers are still holding their bobbin. As follows, African and ant-colonialist scholars said, without economic liberty, political liberty is totally vain. Besides, economic unity makes political unity. Kwame Nkrumah said, "economic unity to be effective must be accompanied by political unity. The two are inseparable, each necessary for the future greatness of our continent, and the full development of our resources." [17] He further said in his Africa Must Unite (1963), the colonial powers had divided Africa by the balkanization. By using balkanization a group of small and large countries was created and in this way Africa became weak and reliant on former imperialist countries (Nkrumah, Africa Must Unite 173). In 1961, Nkrumah explained his vision in his book, $I$ Speak of Freedom, "divided we are weak; united, Africa could become one of the greatest forces for good in the world." [20]

During the cold war, Africa became a pivotal place to the USA and the USSR. Throughout the cold war, two super powers were attempting to dominate in Africa. As a consequence, through the cold war, political instability, civil war and coup d'état were becoming an ordinary issue in Africa. Anti-western scholars said, from 1961 to 1973 six prominent African leaders Patrice Lumumba (Congo), Kwame Nkrumah (Ghana), Silvanus Olympio (Togo), Mehdi Ben Barka (Morocco), AmilcarCabre (Guniea and camp Verde) and Eduardo Mondlane (Mozambique) had been excluded by the pro-western coups. Still now, Africa is the only continent where more than 130 military coups were held. On the other hand, the fate of president Gadhafi is not unknown to us. It is claimed that anti-western activities were responsible for the exclusion of president Gadhafi.

\section{Effect of Colonial Aggression on African Culture}

Of all the areas of the world that scholars have claimed to be adversely affected by colonialism, Africa is probably the most mentionable. Professor Maswood Akhter has written in his introduction to Musings Post Colonies, "It is not the official departure of the colonial machine, by default, has engineered the architecture of a new world- order rather, while the colonies do not exist anymore (of course, we take colony as implying a country under direct administrative set up or structure of governance of another, more powerful country), colonialism happens to continue, albeit without its more obvious signs". [21] In the expansive "age of imperialism" of the nineteenth century, scholars have argued that European colonization in Africa has led to the elimination of various cultures, worldviews, and epistemologies. This arguably has led to uneven development, and further informal forms of social control having to do with culture and imperialism. A variety of factors, scholars argue, lead to the elimination of cultures, worldviews, and epistemologies, such as "de-linguicization" (replacing native African languages with European ones) and devaluing ontology's, that are not explicitly individualistic. Professor Maswood Akhter has mentioned in the same introduction (stated above) that, "The colonized societies have their own set of internal agendas and forces that continue to interact with and modify the direct responses to the colonial incursion. The retreat of the British after the Second World War occasioned the start of political independences for its colonies, but colonialism was not to end with the end of colonial occupation. The obvious signs began to disappear, but the population did not really get that freedom as colonial encounters impacted powerfully on politics, literature and culture of the non- west." [22]Another scholar, Ali A. Abdi, claims that imperialism inherently "involve[s] extensively interactive regimes and heavy contexts of identity deformation, misrecognition, loss of selfesteem, and individual and social doubt in self-efficacy". [23] Therefore, all imperialism would always, already be cultural.

Charles A. Ellwood, an American Sociologist brings out the multifaceted nature of culture when he encapsulates it to mean:

A collective name for all behavior patterns socially acquired and socially transmitted by means of symbols; hence a name for distinctive achievements of human groups, including not only such items as language, tool making, industry, art, science, law, government, morals and religion, but also the material instruments or artifacts in which cultural achievements [sic] are embodied and by which intellectual cultural features are given practical effect, such as buildings, tools, machines, communication devices, art objects, etc.... The essential part of culture is to be found in the patterns embodied in the social traditions of group, that is, in knowledge, ideas, beliefs, values, standards, and sentiments prevalent in the group. The overt part of culture is to be found in the actual behavior of the group, usually in its usages, customs, and institutions.... The essential part of culture seems to be an appreciation of values with reference to life conditions. The purely behavioristic definition of culture is, therefore inadequate. Complete definition must include the subjective and objective aspects of culture. Practically, the culture of the human roup is summed up in its traditions and customs; but tradition, as the subjective side of culture is the essential core [24]

Many of today's academics that employ the term, cultural imperialism, are heavily informed by the work of Foucault, Derrida, Said, and other poststructuralist and post colonialist 
theorists. Within the realm of postcolonial discourse, cultural imperialism can be seen as the cultural legacy of colonialism, or forms of social action contributing to the continuation of western hegemony. To some outside of the realm of this discourse, the term is critiqued as being unclear, unfocused, and/or contradictory in nature.

Indeed, the significant fact about African cultural history is the convergence upon the indigenous tradition of the two external influences- the Arab-Islamic and the EuropeanChristian - to which the continent has been exposed for all over a millennium. The values and lifestyles associated with these traditions have been assimilated and to a large extent indigenized on the continent. The observation provides a broader perspective on the phenomenon of westernization in Africa, an observation made as early as the late nineteenth century by the great African cultural theorist Edward Wilmot Blyden and summed up in the late twentieth century by Ali Mazrui as "the triple heritage." [25] Professor Dare Arowolo in his "The Effects of Western Civilization and Culture on Africa" [26] has mentioned some notable effects on African culture as follows:

- Family/Social Relations: Extended family giving way to nuclear family. Traditional African family values breaking down very rapidly. Extended family that was wonderful instrument like a social verve, social security in our community has given way to nuclear family. Little wonder that there is no more respect for age; no more respect for values that we held sacrosanct in Africa; younger ones now find it very difficult to greet elderly ones.

- Individualism: We now have children of single parents, a phenomenon that is identifiable with America. People no longer communalize, nobody wants to be anybody's brother's keeper.

- Building Pattern: The way we build now is different from the way it was; we no longer take into cognizance our own peculiarity in the building process. We now build houses without ventilation.

- Urbanization: It led to rural exodus and the displacement of large segments of the population.

- Corruption: western civilization has promoted corruption in Africa; leaders in Africa now look up to Europe and America as safe havens for looted funds. It is a consequence of Western civilization.

- Sexuality: The conception of sexuality has changed completely; the desire to be like Westerners by our children has suddenly made them promiscuous; doing things that were never imaginable several years ago. This does not, however, in any way support cultural isolationism. Cultural isolationism is not possible in the context of globalization. Cultural ideas and values grow and flow across borders unimpeded, but that should not make us lose sight of the fact that the weaker you are; the more likelihood of cultural dominance. Africa has been very weak and vulnerable since the last century. Africa now suffer from level of mental enslavement; cultural imperialism; the need for decolonization of the mind. The trend of Western civilization in Africa is pathetic, the strength of wave of Western civilization is such that Africa is hardly capable of resisting it. The wave is so strong that it has become irresistible.

- Language: Proficiency in our language is declining in Africa because we are compelled to embrace Western culture and civilization as Western language; Western language has created a dichotomy between an elite and mass of our people who still cannot do business with foreign language. It causes alienation for people who cannot speak English or French. Language is a vehicle of culture; we are in a very serious problem. Professor Babafunwa project on local language as a basic tool of teaching in Nigeria was aborted because of the nature of our country. We must define and design means of helping Africa out of this language, cultural logjam.

- Christianity: The impact of Christianity has to be considered, for this has been the most important single factor in the process of Westernization in Africa. Western education, involving literacy and the mastery of a European language, became the condition for entry into the modern sector. For most of the colonial period, education was in the hands of the Christian missions, who sought not only to convert Africans but also to inculcate Western values. Christianity challenged traditional belief systems and promoted the diffusion of new ideas and modes of life; in particular, it sought to impose monogamy and the nuclear family as the norm.

- The cultural alteration provoked by the pressures of colonial rule and missionary in all spheres of life are pervasive enough to qualify as the signs of a new cultural coup in Africa. This is more noticeable in the area of science and technology on African experience and consciousness. Modern medicine has largely taken precedence over traditional methods in matters of health.

Mr. Dare also says that:

The trend of cultural westernization of Africa has become very pervasive and prevalent, such that Western civilization has taken precedence over African values and culture and the latter is regarded as inferior to the former. As with other societies and cultures in the so-called Third World, the impact of Western civilization on Africa has occasioned a discontinuity in forms of life throughout the continent. This has led to a cultural dualism that often presents itself as a real dilemma in concrete, real-life situations. In other words, the African experience of modernity is fraught with tensions at every level of the communal and social settings. The post independence Africa is confronted with how to have a true identity, a new culture that is African in nature. ("The Effects of Western Civilization")

But from the perspective of recent cultural expansion of the west, the Africans, instead of harping on the guilt of the colonizers, should take positive and confident steps towards a new era by developing self respect and by increasing their productivity. 


\section{Neo-colonialism and African Literature}

After a long period of oppressive rule, for the collective struggle of the Africans, when the Europeans left Africa, they left their ill-spirits behind them. But the long-cherished freedom could not uplift the conditions of the Africans in general. After the independence the men who attained power were simply the agents of their colonial masters. They became "tax agents and court messengers, and, armored by the new laws and authority, they treated the community without the usual African fellow feeling: their powers and positions had come from elsewhere outside the clan, not from within it". [27] They were much influenced by the outsiders and were guided by the Eurocentric philosophy. This Eurocentric philosophy had been sponsored by the West for political, economic and cultural purposes. For example, it was important for the western imperialists to reject, deform or bastardize the history of the blacks to confirm their mistaken notion of cultural hegemony, and cultural and economic deprivation of Africans. [28] It is for this reason that, still today the Africans, men in power, are loyal to the external authority in Europe and America and not to the African community.

After independence, the African people and writers became disillusioned as the African rulers became worse than their colonial masters. This led to the present phase in which Neo-colonial problems are analyzed and interrogated. These literary works started engaging the description and interrogation of post-independence problems in Africa. Some of the works in this phase include A Man of the People (1996) by Chinua Achebe, The Beautiful Ones are Not Yet Born (1969) by Armah, Petals of Blood (1986) by Ngugi; plays like Once Upon Four Robbers (1980) and Morountodun (1982) by Osofisan, Madmen and Specialists (1971) by Soyinka, The State Visit (2002) by Osundare, Today is not forever (2008) by Agboola Olatunji and poetic works like Village Voices (1984) by Niyi Osundare. In African Literature there is the representation of the above yes-men like people who worked for their European masters. In Nigerian writer Wole Soyinka's play, The Lion and the Jewel, the character Lakunle's (progressive and absurdly westernized teacher) ways are plastic and his language is flowery but without effect, compared to warmed, old Baroka, the typical African whose actions are result-oriented. The Kenyan author Ngugi Wa Thiong'o, in his first novel Weep Not, Child (1964) depicts Jacobo, an important landowner and chief of the village, who treats other Kenyans with insult and supports the white settlers against the natives during the Mau Mau struggle for independence. [29] Obi Okonkwo in Chinua Achebe's novel, No Longer at Ease (1960) is another example. In the novel, he became baptized as Isaac. Achebe's literary objective in his early works, especially in Things Fall Apart and Arrow of God, was to fight back the negative ideas of Africa propagated by the European colonizers and those sharing a similar imperial ideology. [30] In many South African novels, during the apartheid, the black African policeman who, being on the side of the whites, commands and brutalizes his fellow Africans, represent the colonial masters' left behind ill-spirits. These Natives worked side by side with the whites to replace African culture and religion with Christianity and foreign culture. [31] As Sartre summarizes:

The European elite undertook to manufacture a native elite. They picked out promising adolescents; they branded them, as with a red-hot iron, with the principles of western culture; they stuffed their mouths full with high-sounding phrases, grand glutinous words that stuck to the teeth. After a short stay in the mother's country they were sent home, white-washed. These walking lies had nothing left to say to their brothers; they only echoed. [32]

In Africa, to speak the truth, nothing has changed after the independence except the skin colour of the exploiters. The leaders who took power in the post-independence Africa were just the reincarnations of the African Middlemen of the slave trade era. As surrogates, they extended the activities of the previous colonizers and their primary goal in politics has been amassing money through corruption. Their political corruption and the instability resulting in coups and civil wars gave the African writers materials for their art. They started to react against the corruption of the newly attained African rule.

In Ngugi's Petals of Blood (1986), there is the depiction of contemporary African socio-political reality. The novel discusses the intimate relationship between political rulers and the imperialists in Neo-colonial Africa. In the novel, Nderiwa Riera, a local politician, uses people's permission given to him as a "license to amass wealth and barter his nation's interest for profit in joint business with the imperialists." [33] There is the dispossession of peasantry of their land as expressed in the appropriation of Nayankinyua's land. There is the depiction of Kimeira, Chui and Mzigo, who represent the emergence of a parasitic bourgeoisie class. Former peasants, Abdullah and others are replaced by the urban elite property owners. It is ironical that, the people who struggled for freedom and lost many things, kith and keen, and even parts of their bodies like Abdullah, are left to suffer, where as the persons who were against independence like Kimeira become affiliates of the ruling class.

Neo-colonial Africans are the persons who preserve, defend and show the former colonial master's languages, cultures and literatures either directly or indirectly. For example, as Ngugi Wa Thiongo reports, in 1976, the Kenya's CID headquarters summoned him and the then director of his play, The Trial of Dedan Kimathi (1976), and were warned not to interfere with European Theatre- Kenya's National Theatre. [34] To add the list, in Nigeria, while the nation's indigenous languages are rapidly losing speakers, the authority has added French as second official language despite the fact that English was the first official language. [35] Nowadays, among the Nigerian youths, a scornful attitude to African cultural ways is noticeable and it has become a status symbol for them.

In African countries, even today, freedom of expression is 
getting neglected. To make the situation worse, the writers are killed, compelled into exile and their works are either banned or have to undergo so-called censorship. Again, as Joe Ushie writes, there exists stormy publishing climate partially occasioned by the ailing economies and the shift of multinational publishers' interest to rapid-selling school texts. This allows African governments' 'divine' sluice gate to control the flow of otherwise 'poisonous' material into the public. [36] As a consequence, in Africa, writers suffer "more indignities, threats, humiliations and genuine terror than their counterparts in the rest of the non-western world." [37]

In literature, the authorities' suppression to the writers has been perpetuated in Neo-colonial Africa. In Sierra Leone, Liberia Rwanda, and the Congo, many authors have surrendered to the African rulers either by self-censorship or by giving up writing altogether. Others, who still continue writing, have devised a strategy in their writing style. To avoid harassment, they use passive narration. To depict the Neo-colonialist predator Africans, they recurrently use certain symbols like, lions, vultures, jackals, wolves, hyenas, hangman, bayonets, etc. And to portray the victimized, they use symbols like lambs, sheep and skull. [38]

The condition of Africans is deteriorating as the political situation is getting tumultuous and agonizing for the country. In the name of democracy the tyrants are forcing people who are at the mercy of them. Nothing seems to work as the rulers are becoming corrupt. In these circumstances, the African writers are becoming more robust and more sensitive in their reactions against the complex Neo-colonial problems in Africa.

\section{Conclusion}

The imperialist trends of the $18^{\text {th }}$ and $19^{\text {th }}$ century continued till 1945 when the Second World War ended. After the end of the War, imperialism attained a new phase in the polarized world. Consequently, during the post-war period, though the colonial countries like Africa, Asia and others achieved independence, they could not free themselves from the cruel clutches of neo-colonialism. Though time has changed, and side by side the color of imperialism also changed; but the nature of imperialism remained unchanged. For this reason, the entire developing countries including Africa have been the victims of neocolonialism. To get rid of this victimization, it is necessary to sing the songs of humanity, because human beings are for humanity. Men are above all things; nothing is there on top of them.

\section{References}

[1] Northrop Douglas. A Companion to World History. West Sussex (UK): Willi Blackwell, 2012.https://www.marxists.org/subject/africa/nkrumah/neocol onialism/introduction.htm.
[2] https://global.britannica.com/topic/neocolonialism.

[3] Ibid

[4] Jibonanondo Daser Shrestha Kabita (The Best Poems of Jibonanondo Das): Edited by Kazi Siraj. Dhaka: 1991. p. 44. (translated by the authors).

[5] Chamberlain, M. E. The Scramble for Africa. Rutledge: New York, 2013, P. 53.

[6] Ibid.

[7] Hossain, Abu Md. Delwar. Africar Itihas (History of Africa). Dhaka: Bishobidiyaloy Prokashoni, 2016, P. 52-54.

[8] Okoth, Assa. A history of Africa: African nationalism and the de-colonisation process. Nairobi: East African Educational Publishers, 2006, P.3.

[9] Ibid, P. 7.

[10] Birmingham, Professor David. The Decolonization of Africa. London Press (UCL): University College, 1995, P.1-2.

[11] Daily Azad, Dhaka, 30 December, 1965.

[12] Mwakikagile, Godfrey. Africa under Independence: Realities of Nationhood. Darussalam, Tanzania: New African Press, 2009, P.60.

[13] Kwame Nkrumah, Neo-colonialism the Last Stage of Imperialism, p. 2.

[14] www.globalresearch.ca/africas-second-liberation-againsttodays-neo-colonialism/5451647.

[15] Hossain, Abu Md. Delwar. Africar Itihas (History of Africa). Dhaka: Bishobidiyaloy Prokashoni, 2016.

[16] www.globalresearch.ca/africas-second-liberation-againsttodays-neo-colonialism/5451647.

[17] Economic Development in Africa Debt Sustainability: Oasis or Mirage? United Nations, New York and Geneva, 2004, p. 5.

[18] Nkrumah, Kwame. Neo-colonialism the Last Stage of Imperialism. New York: International Publishers, 1965, P.30.

[19] Nkrumah, Kwame. Africa Must Unite. New York: Frederick Praeger. A. Publisher, 1963, P. 173.

[20] http://www.bbc.co.uk/worldservice/people/highlights/000914_ nkrumah.shtml.

[21] Akhter, Maswood. Ed. Musing Post Colonies. Rajshahi: Chinho Publication, 2012, P. 11.

[22] Ibid.

[23] Abdi, Ali A. "Globalization, Culture and Development: Perspectives on Africa". Journal of Alternative Perspectives in the Social Sciences. Vol. 2 (1), 2000, P. 20-26.

[24] Amponash, S. (2010). "Beyond the Boundaries: Toyin Falola on African Cultures" in Niyi Afolabi, ed. Toyin Falola: The Man, The Mask, The Muse. North Carolina: Carolina Academic Press, P. 24.

[25] Irele, F. A. (2010). Westernization. http://science.jrank.org/pages/8152/westernisation. 
[26] Arowolo, Dare. "The Effects of Western Civilization and Culture on Africa" Afro Asian Journal of Social Sciences, Volume 1, No. 1 Quarter IV, 2010.

[27] Joe Ushie (2008). "Two Africas in One: Neo-colonialism and the African Writer." http://www.africaresearch.org/ncol.htm.

[28] Sunday Agboola Olatunji. "Thematic changes in postcolonial African literature: From colonialism to neocolonialism", SinoUS English Teaching, 2010, Volume 7, No.10 (Serial No.82).

[29] Ngugi Wa Thiong'o (1964). Weep Not, Child. Kenya: Heinemann Publication.

[30] Tanure Ojaide (2009). "Examining Canonization in Modern African Literature". Web. N. P. 12 Oct. 2016.

[31] Joe Ushie (2008). "Two Africas in One: Neo-colonialism and the African Writer." http://www.africaresearch.org/ncol.htm.
[32] Fanon, Frantz Fanon. The Wretched of the Earth. Great Britain: Penguin, 1967, P. 7.

[33] Amuta, C. The theory of African literature. London: Zed Books Ltd., 1982, P.145.

[34] Thiong'o, Ngugi Wa. Moving the Centre: The Struggle for Cultural Freedoms. Oxford: James Currey, 1993, P. 2.

[35] Joe Ushie (2008). "Two Africas in One: Neo-colonialism and the African Writer." http://www.africaresearch.org/ncol.htm.

[36] Ibid.

[37] Charles R. Larson (2001). The Ordeal of the African Writer. London and New York: Zed Books. P. 114.

[38] Joe Ushie (2008). "Two Africas in One: Neo-colonialism and the African Writer." http://www.africaresearch.org/ncol.htm. 